\title{
INFLUENCE OF GENOTYPE AND SEX ON THE GROWTH OF CHICKENS UP TO 6 WEEKS OF AGE IN INDIGENOUS SILVER HENS
}

\author{
Danail Šutevski \\ Institute of Animal Science, Ss. Cyril and Methodius University in Skopje, \\ Blvd. Ilinden 92/a, 1000 Skopje, Republic of North Macedonia \\ danail.sutevski@yahoo.com
}

\begin{abstract}
A b s t r a c t: The chicken is one the most widespread birds of the world. Today there are a number of breeds of chickens and are generally divided into meat breeds and egg breeds. Meat breeds are usually heavy and have less laying, with less eggs, while egg breeds are lighter and have more egg productivity, which is up to 270 eggs per year. There are many commercial breeds in the world, but in this paper we will talk about the domestic indigenous silver hen. For the purpose of this paper, data from two genotypes of chickens (Colorful - indigenous, and Gray - idigenous), male and female chickens, were measured and collected to see the growth dynamics of egg-laying breeds. For this purpose 20 chickens from different phenotypes (Gray and Colorful) were hatched and their growth and development over 6 weeks was monitored and observed through exact measurements over a period of 6 weeks. The aim of the study was to capture the knowledge about the productivity of the silver hen, which is native indigenous breed, by analyzing the most important period in growth and development (the first 6 weeks).
\end{abstract}

Key words: genotype, sex; growth; indigenous silver hen; colorful indigenous; gray indigenous

\section{ВЛИЈАНИЕ НА ГЕНОТИПОТ И ПОЛОТ ВРЗ ПОРАСТОТ НА ПИЛИЬАТА ОД АВТОХТОНАТА СРЕБРЕНА КОКОШКА ДО 6-НЕДЕЛНА ВОЗРАСТ}

\begin{abstract}
А п с т р а к т: Кокошката е една од најраспространетите птици на Земјата. Денес постои голем број раси на кокошки и во принцип се делат на раси за месо и раси за јајца. Расите за месо обично се тешки и имаат помала несивост, односно даваат помалку јајца, додека расите за јајца се полесни и имаат поголема несивост, дури и до 270 јајца годишно. Постојат повеќе комерцијални раси во светот, но во овој труд зборуваме за домашната автохтона сребрена кокошка. За целта на овој труд беа измерени и собрани податоци за машки и женски пилиња од две раси кокошки (шарена автохтона и сива автохтона), за да се види динамиката на растењето на јајценосните раси. За оваа намена беа изведени 20 пилиња од различни фенотипови (сиви и шарени) и беше следен, преку егзактни мерења во одреден временски интервал, нивниот развој и пораст во текот на 6 недели. Целта на студијата беше да се добијат сознанија за продуктивноста на сребрената кокошка, која е наша домашна автохтона раса, преку анализа на најважниот период во растот и развојот (првите 6 недели од животот).
\end{abstract}

Клучни зборови: генотип; пол; пораст; автохтона сребрена кокошка; шарена автохтона, сива автохтона

\section{INTRODUCTION}

Poultry products have a significant role in the daily diet of humans, so it is necessary to work on finding new, alternative ways of breeding and new genotypes adapted to local breeding conditions. In this direction, changes are being made in Nort
Macedonia for phenotypic characterization and inventory of indigenous poultry genotypes that would be grown in rural households in extensive conditions, because it is considered to be adapted to the poor diet and breeding conditions in chicken coops. Many reports have been published on the characteristics of different native genotypes of 
chickens in order to offer small, but valuable contribution to these global efforts for protecting the genetic poultry resources. Ceccobelli (2013) [1] has summarized and described the most important traits for several breeds (Albanian, Serbian, Spanish and Italian) in PhD Thesis focusing on molecular tools in analyzing genetic diversity of Mediterranean autochthonous chicken breeds.

The main motive for this paper was to contribute to the knowledge of the growth dynamics of chickens of this autochthonous poultry genotype in order to determine whether the autochthonous Macedonian silver hen belongs to this group of breeds of chickens whose main feature is egg production [2].

Given the topic that is the subject of this paper, it is important to emphasize the following remark: Any delay in poultry development in the first 4 to 5 weeks can result in a reduction in poultry body weight at 16 weeks of age, which will lead to a decrease in egg weight during production or delayed poultry transfer.

\section{Indigenous silver hen}

Probably, few people know that in North Macedonia, a long time ago, there was an autochthonous chicken that existed in rural areas and was characterized as an easy-to-breed bird that differed from other species. In our literature, it is known as the silver chicken. This silver hen can still be found in some rural areas today. Once upon a time, she was the only hen of exceptional importance to rural families. And not coincidentally, because she was economical in her diet, resilient to the conditions in which she lived, both in terms of food and accommodation. In fact, this hen will find a place to live, lay eggs and reproduce on her own. Importantly, the silver hen was very resistant to climatic conditions that were not always favorable for their survival, in such modest conditions, when they are almost left alone, a new genotype will be formed with very modest capacities. Egg yolk was very small, reproduction was certainly achieved by hatching, in fact as today in some underdeveloped rural areas. In favorable weather conditions, the diet is free, the hen ate what she found in the area, and very rarely received food from the breeder. by the color of the ash-silver feathers, but some with colorful colors. Their legs are yellow, light, some even black. Some are small, some are larger. Male individuals - roosters, are described as typical representatives of the Mediterranean [1], i.e. wild type of coloration, red or brown, black, golden, silver combinations often shown as those of the Italian goat or brown leghorn [9]. Hence the name domestic indigenous silver hen.

The most common phenotypes (according to the color of the feathers) among the village chickens are: 1. Light brown with darker black-brown coloring of the neck, wings and tail. 2. Ash-silver-brown (in the type of the Italian goat) feather color with round feathers with different shades of feathers. 3 . Dark black with red or silver Colombian stripes on neck and chest, which was most common (Figure 1).

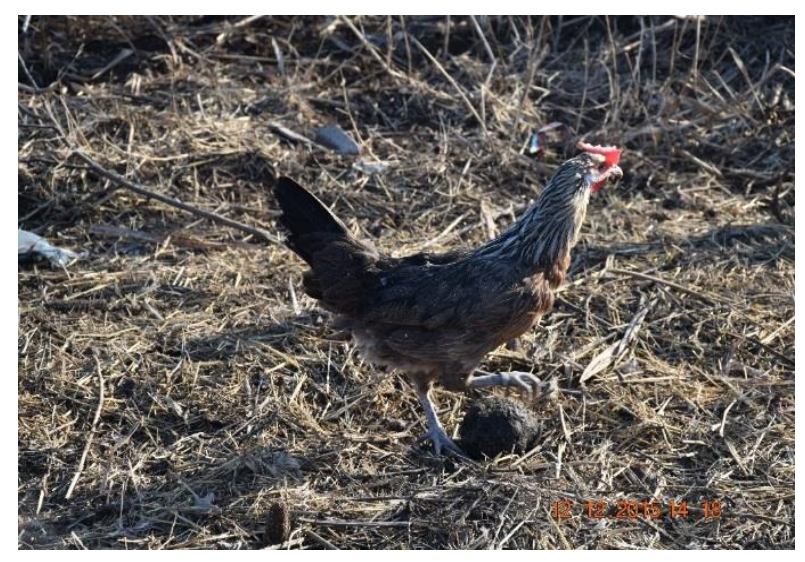

Fig. 1. Genetic providence (genotype)

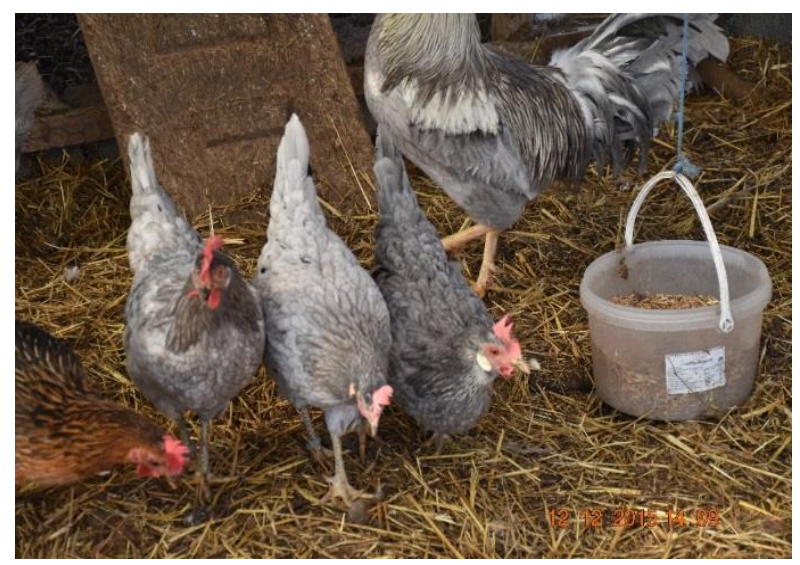

Fig. 2. Genetic providence (genotype) domestic chicken Cinderella - silver brown, chicken blue hue (in the type of fucking Italian)

Through the activities for phenotypic characterization of the autochthonous genotype, two more often present phenotypic variants were additionally determined, as follows: 1 . The so-called gray or blue, or "blue" phenotype (which probably has its roots in some part of the Australoporop breed in combination with domestic chickens, but according 
to breeders has generally been maintained as a population for more than 30 years) (Figure 2). Specific phenotype, i.e. phenotypic form new according to its appearance, with pronounced Colombian colors. These dates were presented in the annual reports on the activities of the Biodiversity Conservation Program Macedonia of the Ministry of Agriculture, Forestry and Water Economy [3 - 8].

\section{MATERIAL AND METHODS}

This paper is based on data recorded in a small farm in Katlanovo when the chickens from the autochthonous domestic village silver hen were raised in the period from 24. 8. 2016 to 5. 10. 2016. A total of 7 male and 13 female chickens were analyzed, which were reared up to 6 weeks of age. There were two groups of phenotypic variants in the analyzed chickens, namely gray (or blue) and colorful (wild type coloring with two darker stripes on the back in the style of the foal Italian) chickens. The gray group of chickens consisted of 4 male and 6 female chickens while the colorful group of chickens included 3 male and 7 female chickens.

Using an electronic digital scale, their growth and development was monitored during the first 6 weeks by measuring live weight every 7 days. With this approach, data were collected for each chicken separately and then with the help of statistical tools of the Excel software package for Windows 7 they were analyzed statistically. The analyses were made by calculating the general average values, the minimum-maximum values, but also the average values for each of the groups (blue, colorful, male and female) separately and the results obtained from such analyses are presented in the Graphs 1 and 2 and Tables 1 and 2 .

\section{RESULTS AND DISCUSSION}

This modest study describes the growth dynamics of the chickens of the indigenous domestic breed of silver hen, for which purpose 20 chickens of different phenotypes (gray and colorful) were bred and was monitored and observed through exact measurements in a certain time interval of their growth and development in over 6 weeks. The aim of the study was to capture the knowledge about the productivity of the silver hen, which we said was our native indigenous breed, by analyzing the most important period in growth and development (the first 6 weeks of life). It is important to note that the examination of the chickens of the indigenous breed took place in original and unchanged breeding conditions (very modest and unsatisfactory feeding conditions, health care and breeding), as opposed to the hybrid breeds which in terms of accommodation.

\section{Dynamics of growth of chickens \\ from the indigenous domestic silver hen}

In addition, graphs and tables with data collected during the measurement of these chickens will be presented. Table 1 shows in more detail the data on the growth dynamics of the indigenous race.

Colorful indigenous was heavier than gray indigenous continuously from the first to the sixth week. Growth dynamics up to the age of 6 weeks in chickens from the genotype of domestic rural indigenous silver hen indicate that it belongs to the so-called egg-laying breeds or genotypes of layers.

Table 2 shows in more detail the data on the average weekly growth of the chickens of the indigenous breed, where the greatest increase of growth occurs by the third week of their development in both genotypes.

\section{Table 1}

Growth dynamics (average live weight from 1 day to 6 weeks of age) of chickens from the indigenous genotypes $(\mathrm{g})$

\begin{tabular}{lccccccc}
\hline \hline Genotype & 1 day & 1 week & 2 weeks & 3 weeks & 4 weeks & 5 weeks & 6 weeks \\
\hline Gray indigenous & 32.45 & 51.00 & 107.40 & 172.80 & 205.20 & 261.40 & 326.70 \\
$\begin{array}{l}\text { Colorful indigenous } \\
\begin{array}{l}\text { Average value for both } \\
\text { indigenous phenotypes }\end{array}\end{array}$ & 34.36 & 56.50 & 114.80 & 177.60 & 207.80 & 281.80 & 342.80 \\
\hline \hline
\end{tabular}


Table 2

Dynamics of the average weekly growth of the chickens from the autochthonous genotypes $(g)$

\begin{tabular}{lccccccc}
\hline \hline Genotype & 1 day & 1 week & 2 weeks & 3 weeks & 4 weeks & 5 weeks & 6 weeks \\
\hline Gray - indigenous & - & 18.55 & 56.40 & 65.40 & 32.40 & 56.20 & 65.30 \\
Colorful indigenous & - & 22.14 & 58.30 & 62.80 & 30.20 & 74.00 & 61.00 \\
Average value for both indigenous phenotypes & - & 20.345 & 57.35 & 64.10 & 31.30 & 65.10 & 63.15 \\
\hline \hline
\end{tabular}

Comparative data on the growth of chickens from the genotype of domestic indigenous silver hen show a significant lag in the growth of indigenous chickens in the period after the 3 rd week of life, most likely as a result of inadequate disease prevention programs (primary coccidiosis).

\section{Dynamics of growth of male and female chickens from the indigenous domestic silver hens}

Live weight in male birds was more uniform in both genotypes than in females where after the third week of growth the colorful genotype progressed more than the gray one.

The preservation of this indigenous breed is uncertain primarily due to the lack of standard procedures and breeding technologies, both in the period of growth (from 1 day to 18 weeks) and in the period of exploitation (period of oviposition). Because of inadequate nutrition and health care programs, but also inadequate growing conditions, growth and development up to 18 weeks is slow, mortality outside the normal technological limits and the presence of specific and nonspecific causes of disease are high. Consequently, the successful work with it requires strict discipline in breeding and adherence to the overall breeding technology.

Because apart from the little information about the grayness and quality of the eggs presented above, there are no other records of this breed of indigenous, domestic, silver country hen, and with our results we can not give a specific answer as to what characterizes this genotype, nor to complete the whole picture of its productive capacity.

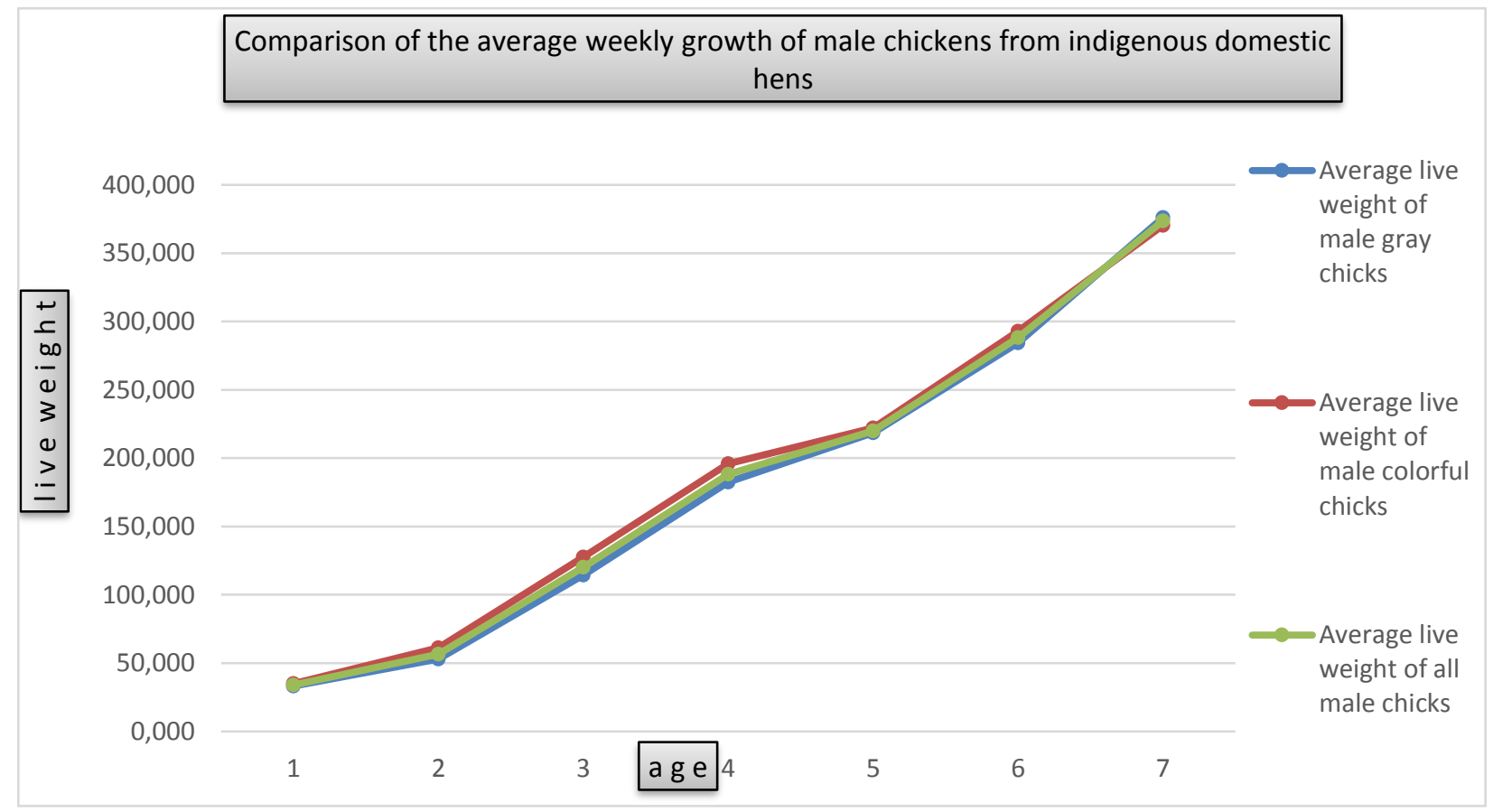

Graph 1. Comparison of growth dynamics up to 6 weeks of age of male chickens from the gray and colorful autochthonous genotype 


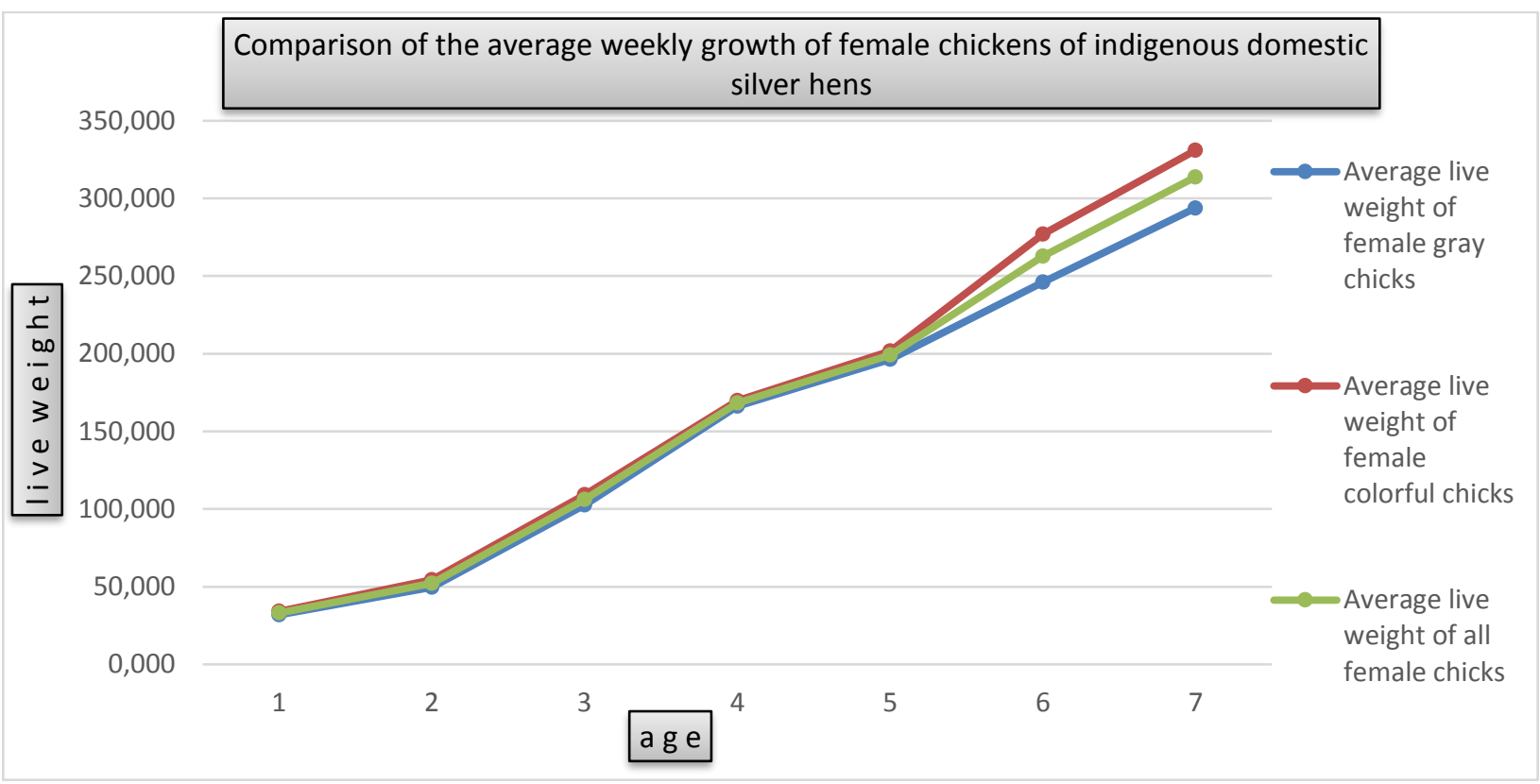

Graph 2. Comparison of growth dynamics up to 6 weeks of age of female chickens from the gray and colorful autochthonous genotype

\section{CONCLUSIONS}

Based on the obtained results, the following conclusions can be made:

1. Growth dynamics up to the age of 6 weeks in chickens from the genotype of domestic rural indigenous silver hen indicate that it belongs to the socalled egg-laying breeds or genotypes of layers.

2. Comparative data on the growth of chickens from the genotype of domestic indigenous silver hen show a significant lag in the growth of indigenous chickens in the period after the 3rd week of life, most likely as a result of inadequate disease prevention programs (primary coccidiosis).

And at the end of this paper on indigenous silver hens, many will wonder why this breed is of particular interest, especially in the scientific world. From the aspect of production properties - it does not satisfy, but if we take into account how we keep it, how we feed it, then we will say that it is a noble being in human life. By studying it further, we will surely learn much more about what has survived and formed over the centuries. So, the general goal is to prevent the extinction of the domestic indigenous silver hen, its selection and expansion of the population and its promotion.

The results obtained from this modest study are only a small contribution to the knowledge of our genotype of a native, village chicken, therefore, it is necessary to continue with further research and research on this breed (genotype) and we hope that the information gained from such research can be used in its preservation by promoting its products on the domestic market.

\section{REFERENCES}

[1] Ceccobelli S: Genetic diversity of Mediterranean autochthonous chicken breeds, $\mathrm{PhD}$ thesis, 2013.

[2] Kocevski D., Bunevski G., Džabirski V., Vuković V., Porcu K., Nikolova N., Tanevski M., Tasev G.: Egg quality characteristics in autochthonous genotypes of chickens raised on Macedonian rural farms. Proceedings of the International Symposium of Animal Science 2014, September 23-25, Belgrade - Zemun, p. 175-181, 2014.

[3] Ministry of Agriculture, Forestry and Water Economy (MAFWE), Law for Livestock, Skopje, R.Macedonia, 2008.

[4] Ministry of Agriculture, Forestry and Water Economy, University "St. Cyril and Methodius", Faculty of Agricultural Sciences and Food - Skopje, Institute of Animal Biotechnology: Kocevski D., Nikolova Nedeljka: Macedonian Indigenous Domestic Chicken, Silver Chicken - Silver, Publication, 2015 ,

[5] Ministry of Agriculture, Forestry and Water Economy, University "St. Cyril and Methodius", Faculty of Agricultural Sciences and Food, Skopje, Institute of Animal Biotechnology Kocevski D., Nikolova Nedeljka. 2016. Implementation of measures and activities from the Program for protection of biodiversity in animal husbandry (2011-2017), Report, 2014. 
[6] Ministry of Agriculture, Forestry and Water Economy, University "St. Cyril and Methodius", Faculty of Agricultural Sciences and Food - Skopje, Institute of Animal Biotechnology: Kocevski D., Nikolova Nedeljka. 2016. Implementation of measures and activities from the Program for protection of biodiversity in animal husbandry (2011-2017), Report, 2015.

[7] Ministry of Agriculture, Forestry and Water Economy, University "St. Cyril and Methodius", Faculty of Agricultural Sciences and Food, Skopje, Institute of Animal Biotechnology: Kocevski D., Nikolova Nedeljka. Implementation of measures and activities from the Program for protection of biodiversity in animal husbandry (2011-2017), Report, 2016.

[8] Ministry of Agriculture, Forestry and Water Economy, University "St. Cyril and Methodius", Faculty of Agricultural Sciences and Food, Skopje, Institute of Animal Biotechnology, Kocevski D., Nikolova Nedeljka. Protection of the indigenous silver hen - silver (educational brochure) 2015.

[9] Manual for breeding indigenous silver hen.Association of Domestic Chicken Breeders Silver Chicken - Silver, Gef program for small grants. 2014. 